\title{
The Centenary of Lithuania's Independence: National Mobilization and Democracy Development throughout Modern Lithuanian History Vilius IVANAUSKAS
}

\begin{abstract}
Modern Lithuania developed consistently in response to external and internal challenges. During the rebirth of the modern nation in the $19^{\text {th }}$ century several vectors emerged that constantly influenced intellectual discourses, politics, and resistance. First, there was the development of national ideology, which aimed at guaranteeing the rights of the Lithuanian nation to establish an independent state. Secondly, the direction of democracy became increasingly evident in the projection and development of the independent state. This article seeks to show the development and overlap of national ideology and democracy, highlighting the main challenges faced in the history of modern Lithuania, discussing the periods of interwar Lithuania, World War II, the Soviet occupation, and contemporary Lithuania, and describing the country's political and ideological trajectories, including the local politics of history. By taking the concept of the nation as a "category of practice" one notices that nationalism became an important factor not only in the liberation from the occupying empires (Russia and the USSR), but also in justifying the new order in the new state or even when challenging democracy. However, development of democracy in many situations coexisted with manifestations of nationalism. Yet during certain periods of modern history it became problematic and embraced experiences similar to those of other Central and Eastern European countries dealing with autocratic tendencies during the interwar period or responding to growing populism recently. The dominating presence of Tsarist Russia, the Soviet Union, and Putin's Russia always played a significant role in the determination of Lithuanians to have a nation-state, and these experiences strongly affect not only the current geopolitical orientation of the country, but also mobilization of patriotism (nationalism) and the politics of history. The responsibility of the Soviet past is often based on totalitarianism as a practical category, exposing the constant threat of "the evil empire", which helps to legitimise today's political, cultural and economic development. At the same time, this politicization of history serves as a tool in confronting and resisting Russia's policies in the region.
\end{abstract}

Keywords: nationalism, national ideology, democracy, Lithuania, independence, centenary, politics of history, Soviet Union, Russia

\section{Introduction}

The year 2018 can be viewed as a return to historical thinking in Lithuania. It was not restricted only to the celebration of February 16th, but also generated recent discussions about the Lithuanian partisans, responded to Moscow's narra- 
tives on WWII, the Lithuanian occupation and the Molotov-Ribbentrop. It also brought forth disputes over the involvement of Lithuanians in the Holocaust. The return of history is also noticeable in the slogans of radical right activists when Lithuania is now perceived as being on the eve of Sąüdis, or, controversially, is regarded as too distant from the ideals of those who helped create the state and too much devoted to the European path of neoliberal ideas ${ }^{1}$. Like never before, history inspires Lithuanian society to retrace and bring back the memory of the struggles for the historical Independence, the partisan resistance or the events of January 13th, to create films, to visit the participants of these battles and their relatives, take pictures of monuments and graves of the state's heroes. History serves as an inspiration to separate from the Soviet past and to emphasize current achievements, or, on the contrary, to criticize the current situation and escalate Soviet nostalgia. History unites and divides the Lithuanian society. It becomes the spontaneous force on which Lithuanian citizens today build not only the collective identity of the state, the nation, and society, but also their group identity; in addition, it supports, condemns or provides material for politics, memory, and identity. History will even gain more importance when local elites and the population continue discussions about sensitive topics, such as the first president Antanas Smetona's authoritarianism, the Holocaust, Soviet-era culture, the rise of the national movement Sąjūis at the end of the 1980's, or the incursion of liberalism in the 1990s.

In this article, I seek to reveal how the dynamics of national mobilization and democratic values as overlapping discourses throughout the modern history of Lithuania responded to various external and internal challenges and were displayed through political and ideological shifts, including local politics of history. The British historian E.H. Carr once wrote that historical truth lies somewhere between valueless facts and value judgements ${ }^{2}$. The Lithuanian field of history is surrounded by various actors, who have values and interests and seek to highlight particular moments of this history. The twentieth century, described by Hobsbawm as the age of extremes, was rich in events. Such political interventions are closely related to the traumatic historical events in Lithuania. From the beginning of the 20th century until today, i.e. during the period from the forced entry into the Russian Empire to the free integration into the European Union, Lithuanians suffered two world wars, three occupations, the tragedy of the Holocaust, the Cold War, and three attempts to restore Independence, of which two were successful, while the one in 1941 ended as a Nazi occupation

1 Vilius Ivanauskas, „Ne už tokią Lietuvą dejjome parašą: istorijos politika posovietinèse Lietuvos kultūrininkų trajektorijose“, Darbai ir dienos, No.2 (62) (2014), 209-227.

2 E. H. Carr, What is History? (Paperback, 1964). 
in 1941-1944. There were many traumatic moments that understandably dominate history. As Jan Marinus Wiersma points out, the first man on the moon is not the subject of much controversy, the legacies of Hitler and Stalin are ${ }^{3}$. Similar discussions are especially valid for the Baltic states, which deal with the permanent necessity to secure their independence, to manage their responses to controversial moments of history-from the Holocaust to Soviet collaboration-and to ensure an appropriate level of democracy at home. In this context, by taking the concept of the nation as a "category of practice," 4 and nationhood as the product of cultural and political institutionalization, ${ }^{5}$ the famous theorist of nationalism Rogers Brubaker describes "nationalizing nationalism" in the territories of former empires as motivated by the claims of formerly marginalized ethnic groups which have since established states. According to him, such groups often define themselves in ethno-cultural terms, claiming that together they compose a "core nation" or nationality. These groups likewise claim that this professed status entitles them to control over the state. In addition to these central claims, those promoting nationalizing nationalism often couple their demand for legitimate "ownership" of the state with emphasizing the legacies of discrimination directed against them. These observations help to understand the logic of the politics of history in the Baltic states, where the narratives of "victims and heroes" are forcefully emphasized, while at the same time historical moments when the "core nation's" representatives behaved immorally in various situations tend to be rejected. However, even if the concept of "nationalising nationalism" helps to identify the situations when local elites persistently emphasize the identity of the victim or encourage the ethno-cultural domination of the core nation, Rogers Brubaker's perspective is not sufficient and lacks the insight that those countries still are civic states based on democratic values. In his article, Taras Kuzio debates with the arguments presented by Brubaker and argues that all civic states (including Western European ones) to varying degrees promote public (societal) cultures that are based upon the language, history, symbols, religion and culture of the core, titular nation $(s)^{6}$. He claims that the majority of post-communist countries are territorial, civic and inclusive democracies, as defined by their willingness to allow integration for all into the

3 Jan Marinus Wiersma, „Politics of the Past: The Use and Abuse of History“, in Politics of the Past: The Use and Abuse of History (Antilope, 2009).

4 Rogers Brubaker, Nationalism Reframed: Nationhood and the National Question in the New Europe (Cambridge: Cambridge University Press, 1996), 7.

5 Brubaker, Nationalism Reframed..., 37.

6 Taras Kuzio "Nationalising states or nation building? A critical review of the theoretical literature and empirical evidence”, Nations and nationalism, no.7 (2) (2001), 145-146. 
societal culture 7 , and in the case of Lithuania he acknowledges that Lithuania is a democratic and plural-liberal state ${ }^{8}$. Following these two perspectives, this article argues that in certain cases local Lithuanian elites implemented „nationalising" actions, but at the same time the approach of keeping a balance between the vectors of nationalism and democracy dominates.

\section{The early period: from Nation building to Soviet Occupation}

On February 16, 2018, Lithuania celebrated not only the Centenary of the Restoration of the State but also of democracy. The Act of Lithuania's Independence on February 16, 1918, proclaimed the State of Lithuania, which was based on the foundations of democracy. Nationalism and democracy-these two lines overlapped in the struggle for freedom in modern Lithuanian history and these two vectors were very important from the beginning of the national movement and nation building in the $19^{\text {th }}$ century. In Lithuania, the formation of the modern nation in the 19th century took place belatedly and at a particularly high speed 9 . The intensification of the national revival began with two early newspapers, Aušra and Varpas, led by two intellectuals Jonas Basanavičius and Vincas Kudirka. In 1883, the first newspaper, Aušra, was published, in the circle around Doctor Basanavičius, It escalated national consciousness and historical memory, romanticism, and resistance to the oppression of the tsarist government. Aušra published a lot of different articles on Lithuanian history and frequently depicted the character of the nation ${ }^{10}$. The co-workers of Aušra included of right-wing liberals (Petras Vileišis), democrats (Juozas AndziulaitisKalnènas) and left-wing liberals (Jonas Šliūpas). The romantic Basanavičius preferred a secluded study of people's customs and history to active social work $^{11}$. The generation of Basanavičius read widely and eclectically-the Polish romantics (especially Mickiewicz, Syrokomla, and Slowacki), the "Sturm und Drang” poets, German philosophers, as well as Byron, Garibaldi, Kossuth and other romantics and nationalists ${ }^{12}$. Another newspaper, Varpas, founded in 1889 , began to raise the principles of people's independence, democracy, and civic rights. Varpas expressed and highlighted these principles and also relied on pragmatic ideas, linking national cultural issues with economic affairs, such

\footnotetext{
7 Kuzio "Nationalising states"148.

8 Kuzio "Nationalising states" 149.

9 Tomas Balkelis, The Making of Modern Lithuania (Routledge, 2009).

${ }^{10}$ Kamilè Černiūtè. "Lietuviškosios istorijos ir paveldo paieškos Aušroje 1883-1886 m., Naujasis židinys-Aidai, no.8.

${ }^{11}$ Balkelis, The Making of Modern Lithuania..., 20.

${ }^{12}$ Balkelis, The Making of Modern Lithuania..., 23.
} 
as land reform, credit, crafts, schools, health issues, improvement of communication channels, etc. Aušra wrote quite cautiously about relations with the Russian authorities, while Varpas demonstrated a more open opposition to tsarist policies in Lithuania, courageously raising the question of Lithuanians to local authorities and condemning the policy of oppression. Mykolas Romeris, in his book Litwa (1908), comparing Aušra and Varpas, said that Aušra represented youthful enthusiasm, while Varpas was the act of a mature and self-confident man. As historian Česlovas Laurinavičius argues, Basanavičius embodies the national line, while Kudirka brings democracy to the national movement ${ }^{13}$.

These two vectors ere also visible in the rebirth of Independence. Lithuania was manoeuvring between Bolshevik Russia and Germany at the end of 1917 and the beginning of 1918. On December 11, 1917, the Council of Lithuania proclaimed the declaration of Lithuania's Independence, but at the same time confirmed a close alliance with the German Empire. The political situation then changed, and Lithuania proclaimed another act of Independence in February 1918, which did not link Lithuania's development with other states and mentioned the democratic system and the necessity for an elected parliament (Seimas). The two years from 1918 to 1920 were marked by battles for independence with Bolshevik Russia, Poland (Lithuania lost Vilnius) and the Bermondtians, but Lithuania finally defended its independence at the cost of losing Vilnius to Poland. Lithuania did not repeat the fate of the Caucasian nations, which occurred under the Soviet regime. The elections to parliament took place on April 14-15, 1920, after which a Constituent Seimas was elected, and almost all political figures in Lithuania agreed that the future political system of Lithuania would be a democratic parliamentary republic. The parliamentary republic (based on the French example) was finally consolidated in August 1922, when the permanent constitution was adopted. During the course of a few years, two pillars were secured-independence and democracy. Democracy was damaged in 1926, when military units organized a coup and Antanas Smetona (until 1940) became an authoritarian president. Smetona implemented nationalist policies and there was little chance for political participation for other political groups, except for the nationalist party (tautinin$\mathrm{kai}$ ). However, the authoritarian regime was not very strict and did not reach the level of fascism, as in Italy, or early Nazism, as in Germany. The rights of national minorities were secured. Besides that, the authoritarian regime led to

${ }^{13}$ Česlovas Laurinavičius, Pasvarstymai apie Vasario 16-osios akto teorines ir praktines ištakas, Roundtable discussion "Apskritojo stalo diskusijos vieni iš daugelio: Lietuvos Nepriklausomybès akto signatarų indèlis kuriant Lietuvos respubliką”, Lithuanian parliament, February 9, 2018. 
the emergence of protest groups, especially on the left, whose individual leaders flocked to the Soviet Union and later facilitated the Soviet occupation of Lithuania ${ }^{14}$.

\section{Historic pages of the Occupations}

Lithuania lost its independence to the Soviet Union in 1940 and to Nazi Germany in 1941-1944. In June 1941, after the German invasion of the USSR, Lithuanians staged an uprising against Soviet power and proclaimed independence, but soon the German occupation was established and the Holocaust occurred in Lithuania. Together with the Nazis, some local collaborators, especially paramilitary groups, also participated in the killing of the Jewish people ${ }^{15}$. Lithuania was again occupied by the Soviets in 1944. During several mass campaigns, many people were deported to Siberia, and numerous young men chose resistance and fought a guerrilla war against the Soviets until 1953, when they were defeated by Soviet forces. They were expecting to receive assistance from Western countries, especially from the United States, but they did not receive any help. It is important that the partisans in 1949 issued a declaration, wherein Lithuania was named as a sovereign country, based on the standards of the democratic 1922 constitution. Post-war partisan resistance was one of the most heroic acts of the nation in modern Lithuanian history, but, as historian Mindaugas Pocius concluded in his monograph, among partisans there were some groups that carried out death sentences not only for Soviet collaborators, but also for some innocent people ${ }^{16}$. This fact was strongly manipulated and emphasized during the Soviet period, when it was attempted to show that all partisan resisters were bands of criminals.

After the partisan fight was defeated, Lithuania succumbed to the black and grey pages of Soviet history, when the local Soviet elites took the role of collaborators or conformists and helped to legitimise the Soviet order. An analysis of Stalinist intellectuals (e.g. Aleksandras Gudaitis-Guzevičius, Teofilis Tilvytis, and others) in the post-war era reveals that cultural workers and local nomenklatura had to absorb images of this "new life" being spread from the Centre, and imposed by discipline and repressive measures, leaving almost no space for creative and organic national expression.

\footnotetext{
${ }^{14}$ Mindaugas Tamošaitis, Didysis apakimas. Lietuvių rašytojų kairèjimas 4-ajame XX a. dešimtmetyje (Vilnius, 2010).

${ }^{15}$ Hektoras Vitkus, "Lietuvos šauliai, Latvijos aizsargai ir Estijos kaitseliitai Holokausto akistatoje: lyginamoji analizè, Lituanistica, T. 61. No 3(101) (2015), 196-220.

${ }^{16}$ Mindaugas Pocius, Kita mènulio pusé: Lietuvos partizany kova su kolaboravimu 1944-1953 metais (Vilnius: 2009).
} 
Under Khrushchev, the situation visibly changed. The generation of the sixties ${ }^{17}$ offered more opportunities for new forms of intellectual life. Ideological controllers no longer required such dogmatism and wanted more flexibility to disseminate Soviet ideology. Thus, a significant part of the Soviet intelligentsia in Lithuania became nationally-oriented, and during the post-Stalinist period it started the mobilization of national identity and began an indirect confrontation with the centralization and homogenization trends, as well as with the most pronounced Russification policies. An important intellectual to discuss would be the poet Justinas Marcinkevičius. Born in 1930, he started his career by adhering to Soviet universalist values, but increasingly turned to ethno-historical topics. His historical plays ("Mindaugas”, "Mažvydas" "Katedra"), written at the end of the 1960s and the beginning of the 1970s, received enormous recognition local audiences and also the nomenklatura ${ }^{18}$. He was the most recognized poet in Soviet Lithuania from the mid 1960s onwards. He followed the line of "localisms," that reflected similar processes supporting ethnic values not only in Lithuania, but also in other republics (e.g. derevenskaya pro$z a)$. The turn of cultural figures towards a greater emphasis on ethnicity in the 1960s signalled an important change: the historical past and heritage were gradually introduced as having value in themselves, without overly emphasizing current parallels. Changes of ideas and appeals to the preservation of norms or gradual change were quite clearly visible in the course of conferences held by writers or other intellectual groups.

The traditionalist line of escalating Lithuanian ethnicity, presented through the prism of heritage and folklore ${ }^{19}$, was considered a quite legitimate position in official rhetoric even before perestroika and eventually became the de facto dominating "new ideology" in the local field of writers' work, actively reacting to and opposing the central objectives of homogenization of society, Russification and the solution of the "merging of nations." On this basis, it strongly engaged in shaping the "grand narrative" of Lithuanian cultural production (in relation to national policy), which became oriented towards historicity and ethnic nostalgia. This position partly agreed with the attitudes of the local nomenklatura of the time, but superseded it by its attention to the dynamics of forming the titular national culture and resisting the objectives of homogeni-

\footnotetext{
${ }^{17}$ Juliane Furst, Stalin's Last Generation: Soviet Post-War Youth and the Emergence of Mature Socialism (Oxford \& New York, Oxford University Press, 2010).

${ }^{18}$ Vilius Ivanauskas, "Sovietinis režimas ir kultūrinès nomenklatūros kaita vèlyvuoju sovietmečiu Lietuvoje. Rašytojų aplinkos atvejis”, Politologija 4 (2010), 53-84.

${ }^{19}$ Violeta Davoliūte, The Making and Breaking of Soviet Lithuania: Memory and Modernity in the Wake of War (BASEES/Routledge, 2013).
} 
zation. Prominent poets from the younger generation, like Marcelijus Martinaitis ${ }^{20}$ and Sigitas Geda, promoted village nostalgia, peasant values, and local mythology. Alongside the bard culture, it became widespread in local society, especially among the younger generation. ${ }^{21}$ Geda's texts were also used in the repertoire of operas or the oratorio entitled The Last Rituals of Pagans (1978) and The Thrush - A Green Bird (1981) by Bronius Kutavičius, an alternative composer of intellectual music. "Blossoming of the nations" was gradually conceived to be more harmful than useful. For these figures, there were too many restrictions and too little room for creativity in the Soviet field of "culture". Questioning of various Soviet modernization projects in different spheres became increasingly trendy among Lithuanian cultural workers in the 1970s and at the beginning of the 1980s. These groups did not accept the ambition of the local nomenklatura to view the Soviet modernization in terms of achievements, but, at the same time, they stated that in certain spheres the local elite members created a meaningful discourse for the break-up of the system, especially on the level of ideas. This was achieved by supporting the line of "national identity" and marginalizing pure Sovietization within the framework of "the blossoming of nations" (rastsvet narodov). While Vincas Kudirka's ideas about democracy de facto were still marginalized, certain ideas of Jonas Basanavičius were openly expressed, legitimising the $19^{\text {th }}$-century Lithuanian national revival and connecting it with the social class movements. Even Kudirka's merits for the so-called "progressive national development" were acknowledged. It is interesting that even in the middle of the 1950s, after all the campaigns against "bourgeois relics", Jonas Basanavičius and Vincas Kudirka were not completely ousted from the field of official memory and symbolic dissemination ${ }^{22}$. Their legacy was preserved at a certain scale, but the interpretation of their ideas could be framed only by a proper Marxist assessment.

This increasing assertiveness of national mobilisation was strongly related to the belief in "socialism with a human face", which was the vision of the generation of the 1960s, and was also oriented towards certain standards of the Western style of modernisation. However, the position of those official intellectuals did not express a deep-seated orientation towards the standards of democracy, and did not challenge the Soviet system. It did not openly formulate any criticism towards the political regime and did not emphasize the vision of independent Lithuania.

${ }^{20}$ Macelijus Martinaitis, Kukučio baladès: Eilèraščiai (Vilnius, 1977).

${ }^{21}$ Rūta Oginskaitè, Nes nežinojau, kad tu nežinai. Knyga apie Vytautą Kernagi (Vilnius, 2009).

22 The correspondence of Deputy minister of Soviet Lithuania T. Černiauskas to the Chairman of Lithuanian Writers' Union A. Venclova, March 11, 1955, LLMA, 34, 1, 176, p. 84. 
The latter position was taken by some Lithuanian dissidents when the defence of human, religious and national rights strengthened in Lithuania ${ }^{23}$. The wave of the human rights movement could be observed in the mid-1970s, when the international Helsinki Act of Human Rights was signed. The Helsinki Final Act was signed on August 1, 1975, by Soviet General Secretary Leonid Brezhnev and thirty-four other world leaders. It was published in Soviet newspapers and inspired the formation of human rights monitoring groups across the Soviet Union ${ }^{24}$. For several months, it was a legitimate activity, but soon the KGB started to prosecute individual activists. In Lithuania, there were several forms of dissident activities. For instance, the dominant line was the movement of supporting the rights of the Lithuanian Catholic Church. Several activists began publishing the underground journal Chronicle of the Catholic Church, and it became the first underground publication after the partisan resistance. The Chronicle wrote not only about persecuted and disobedient believers, violations of their rights, interference of the Soviet government in the life of the Catholic Church, but also expressed the ideas of the "oppressed nation", and these ideas were strongly directed towards criticizing the political regime. These ideas of an independent Lithuania were forcefully developed by another dissident group. In 1978, the famous dissident Antanas Terleckas and his companions established the Lithuanian Freedom League, which, for the most part, declared its final goal to be the restoration of independent Lithuania. The most prominent example of the activities of the Lithuanian Freedom League was the signing and publication of the Memorandum of 45 Baltic people, which was issued together with several activists from other Baltic republics. Also, there were dissidents who strongly supported the ideas based not only on the national rights, but also on individual rights. The case of poet Tomas Venclova reveals the more nuanced nature of Lithuanian cultural opposition, which, alongside the human rights, embodied not only an anti-systemic national movement, but also certain manifestations of democratic standards and individualism.

The case of Tomas Venclova within the Lithuanian intellectual milieu was very much out of the ordinary. Having grown up in the environment of the Soviet cultural elite and having lived in Moscow for some time, he submerged himself into the circles of the liberal intelligentsia, socialized with poets who were criticized by the authorities, and became friends with one of the best-known Russian poets, Joseph Brodsky ${ }^{25}$. He supported dissident individualism and democracy,

${ }^{23}$ Lyudmila Alekseeva, Soviet dissent: contemporary movements for national, religious and human rights (Wesleyan University Press, 1987).

${ }^{24}$ Sarah B. Snyder, "Human Rights in the Cold War," in Artemy Kalinovsky and Craig Daigle, ed. The Routledge Handbook of the Cold War (New York: Routledge, 2014), 237-48.

${ }^{25}$ Josif Brodskij, Poetas ir proza (Joseph Brodsky, Poet and prose), ed. Tomas Venclova (Vilnius, 1999), 121. 
like Moscow's democratic dissidents Amal'rik, Vol'pin and Alekseeva ${ }^{26}$. It seems that the failure to identify with the circles of the local intelligentsia and his close ties with the Moscow dissidents pushed the writer towards a more open confrontation with the system through his participation in the human rights movement $^{27}$. Tomas Venclova became one of the founders of the Lithuanian Helsinki Watch group, which was established in $1976^{28}$. With the confrontation between Tomas Venclova and the authorities intensifying, in 1977 he was issued a permit to emigrate to the West. Apparently, his Communist father's authority played a role in this outcome.

The local Soviet intellectuals and the local dissidents differed not only in their relations with the Soviet establishment, but also in the scale of their ambitions: the local Soviet intellectuals were determined to pursue cultural nationalism, which at that time complied with Soviet agendas, whereas the dissidents clamoured for political nationalism. However, those positions came together during the national revival at the end of the 1980s, when, under the influence of Gorbachev's perestroika, the prominent local Soviet intellectuals established the national movement "Sąjūdis", which took over the dissidents' ideas.

\section{The National Revival at the end of the $1980 \mathrm{~s}$}

In 1988, the newly elected Chairman of the Lithuanian Writers' Union, Vytautas Martinkus ${ }^{29}$ acknowledged the changed climate in Lithuania: "[The fact that] our meetings are open to the public has become well-known in Lithuania. During these meetings, we do not complain about artistic expression or interpretation of values. We can write about the tragic and dramatic pages of our history, about the present paradoxical and controversial times, but, at the same time, we are not the political prisoners of one social doctrine. We are learning pluralism. The situation has changed, and writers are free as they have never been before." The meeting of the Writers' Union at the end of 1987 or in early 1988 was a real start for a wider public discussion on the traumatic moments in Lithuanian history, on the demand to protect natu-

${ }^{26}$ Ann Komaromi, "Samizdat and Soviet dissident publics" Slavic review, vol.71, no.1 (Spring 2012), 70-90.

27 The prominent Russian dissident Lyudmila Alekseeva remembers that Tomas Venclova was one of her main assistants on the issues of human rights and in the attempts to found Helsinki groups when she came to Lithuania in the mid-1970s. See: Lyudmila Alekseeva, Pol Goldberg, Pokoleniye ottepeli (Moscow, 2006), 432.

${ }^{28}$ Lyudmila Alekseeva, Soviet dissent: contemporary movements for national, religious and human rights (Wesleyan University Press, 1987), 80.

${ }^{29}$ IV tarptautinès lietuvių literatūros vertèjų ir leidèjų konferencijos "Lietuvių literatūra internacionalinès literatūros kontekste: paralelès, sąsajos savitumai” medžiaga, 1988 m. rugsėjo 14-15 d., LMA, 34, 1, 1003. 
re from the construction of the Ignalina nuclear plant, or about the oil platform in the Baltic Sea near Kaliningrad. The mobilization of ethnic identity during late socialism had the potential to escalate into political nationalism, while the growing ethnic and national processes felt the threat of Russification coming from the Soviet government. Nationalism scholar Marcus Banks (Marcus Benksas) has analyzed the conversion of ethnic interests into political nationalism. For instance, the Board Plenum of the local Writers' Union of 29 December 1987 was highly symbolic. It did not just focus on traditions and heritage issues but declared the Soviet behaviour in the past to be unfair and harmful, mentioning the time of zhdanovshchina in 1946-1948, when prominent local authors were harshly criticized. The suggestion of the writer Juozas Aputis that it was time to rehabilitate the people who had been attacked in public in 1946 was supported by the chairman, A. Maldonis and by the Secretary of the LCP, L. Šepetys. A. Maldonis said: "We have brought to the attention of the CPSU Culture Department that the decision of 1946 should be withdrawn, since many of the charges were groundless."

Publications of the writers or other intellectuals led to an escalation of the national theme in the spring of 1988. The Founding group of Sajüdis was launched on 3 June 1988. The major part of the 36 members was from the humanities, including authoritative writers, composers, painters, as well as leaders of creative unions. There were six people from the Writers' Union, the same organization which was actively used for the legitimisation of the Soviet order more than 40 years earlier. Now the members of the same organization actively used the "oppressed nation's" discourse, delegitimizing the Soviet order and referring to Lithuanians as victims living under the domination of the USSR. Involving the same participants of cultural processes, this discourse emphasized the previous positioning of traditionalism/critique of Soviet modernism, and used the self-centred attitude of the local cultural and technocratic elite. The words from Justinas Marcinkevicius's drama, Mažvydas, 'Lie-tu-va' (Lithuania), were chanted at mass meetings held during the national revival at the end of the 1980s. During the years of the national revival, Dalia Grinkevičiūte’s book, Lithuanians by the Laptev Sea, which described the Soviet deportations, was published with the support of the prominent poet Justinas Marcinkevičius. It became one of the cornerstones for the "oppressed nation" narrative. In 1989, this new narrative of "oppressed Lithuanians" was not only fully crystallized, but had somehow become routine. This tendency actively involved cultural workers and the wider local intelligentsia, who emphasized their particularism within the Soviet imperialistic discourse during the Soviet era, and then gradually started to support the spread of traditionalism. Jonas Avyžius, in April 1989, in the weekly newspaper Litera- 
ture and Art, wrote, "If a former Lithuanian peasant during many centuries sweated while accumulating wealth for the nation, leaving little for himself, then after forced collectivization, which crushed his spine, with bloody tears he watered the land of his grandparents, trampled by his parents. This land now belonged to someone else." 30

This discourse of the "oppressed nation" also actively used and incorporated other discourses, especially those coming from Lithuanian dissident milieus and underground activities or from the earlier positions of émigrés. Lithuanian émigré organizations actively promoted and escalated the positive attitude of the US towards "breakup in the Baltics" (V. Landsbergis's concept) ${ }^{31}$, adding more legitimacy to the "oppressed nations" discourse and furthering the aims of liberation. The dissenting groups and their long fight was also a significant source for visualizing the inhuman nature of Soviet control and repressions. At the same time, there was a competition between discourses. In certain situations, some other dissidents did not want to recognise the superiority of Sajūdis, comparing it with their own organizations. The cases of the Kaunas group of Sajüdis or of the Lithuanian Freedom League, led by Antanas Terleckas, revealed this tension. The cultural production, created within Soviet official channels, was regarded with scepticism among local dissidents, even if it helped to produce direct or indirect critiques towards a particular party position or towards certain bureaucratic decisions. Nevertheless, it expressed a dynamic relation between all these trends. Local Soviet intellectuals embodied the moderate line of national revival, while dissidents favoured the radical one ${ }^{32}$. In the changing political situation, this multi-layered discourse and metaphorical expression of the "oppressed nation" was a practical tool rather than an analytical one, but it successfully reacted to the demands of society, and the local elites efficiently adjusted the victimisation narrative to the new conditions, presented it on the international level, and dissociated it from more radical positions.

The discourse of the "oppressed nation", which was increasingly supported by both groups, including the dissidents and prominent local intellectuals, was an important source for seeking independence, emphasizing that the Soviet system was harmful and did not reflect the interests of the Lithuanian nation. This position was taken over by the local communist elite, which on October 21, 1988,

30 Jonas Avyžius, Mūsų tautos šaknys, Atgimimo balsai, sud. J.Šlekus (Vilnius:Lietuvos rašytojų sąunga), 197.

${ }^{31}$ Vytautas Landsbergis, Lūžis prie Baltijos. Politinè autobiografija (Vilnius: Vaga, 1997).

${ }^{32}$ Sajūdžio ištakų beieškant: nepaklusniujų tinklaveikos galia, eds. J. Kavaliauskaitè ir A. Ramonaitè (Vilnius, 2011); Rytis Bulota, "SSRS reformų išvakarèse: nomenklatūra ir inteligentija Lietuvoje“" Darbai ir dienos, no. 49 (2008), 69-80. 
elected its new leader, Algirdas Brazauskas, who was more reform oriented than his predecessors. The local communist party did not automatically absorb the ideas of independence, but it increasingly moved towards the requirements of autonomy from Moscow and the central communist party. Despite the fact that Sąjūis held to a nationalist direction, it also maintained a constructive relationship with the Communist Party and influenced its transformation by changing the leader (Algirdas Brazauskas replaced Ringaudas Songaila) and separating from the all-Union Communist party in $1989^{33}$. Both Sąūdis members and local communists kept balancing each other, while the communists were protagonists of trends towards wider autonomy and kept the balance in relations with Mikhail Gorbachev in the path to independence. At the same time, Sąjüdis's proponents increasingly articulated the goal of Independence. After the successful elections in early 1990, they pushed their agenda and proclaimed Lithuania's independence on March 11. The Lithuanian communists accepted this step, but at the same time they were hesitating and questioning whether it was not too early for this stage. They emphasized more risks of such a decision (e.g. economic dependence, international recognition of Gorbachev, etc.) than Sąjūdis members did. However, this loyalty (voting "yes") helped them to remain a significant force in the Lithuanian political landscape. Another reason for the continuity of their status was the fact that they, like many leaders from Sajūidis, were "systemic" people, i.e., they came from the local cultural, party or economic elite, they were not open dissidents, despite the fact that some of the Sąjūdis members became increasingly radicalized. This factor of being systemic and progressive at the same time helped to integrate some more flexible leaders (e.g. Algirdas Brazauskas, Justinas Karosas, Vladimiras Beriozovas, Gediminas Kirkilas) into the changing political landscape. The new political elites did not have enough legitimate power to marginalize their communist opponents. However, communists were also important as a balancing force between Sąūidis leaders and the Centre in 1990-1991, keeping the illusion that there was still a possibility to find a compromise and to re-discuss Lithuania's status and its relationship with the USSR.

\section{Challenges to the Independent State}

It can be concluded that the national revival of 1988-1990 was driven by the national revolution, which increasingly overlapped with the liberal revolution and democratic ideas ${ }^{34}$. National ideas overlapped with the ideas of the free market,

${ }^{33}$ Česlovas Laurinavičius, Vladas Sirutavičius, Sajūdis: nuo „Persitvarkymo“ iki Kovo 11-osios (Vilnius, 2008); Danutė Blažytė, „Lietuvos elito ịtaka komunistinès struktūros transformacijai ị politinę partiją“. Lietuvos istorijos metraštis, 2000 metai (Vilnius, 2001).

${ }^{34}$ Bruce Ackerman, The Future of Liberal Revolution (Yale University Press, 1992). 
liberalism or, as critics called it, the wave of neoliberalism. The creation of a democratic state was inseparable from the maintenance of the free market, with the growing importance of public opinion. At the same time, by distancing themselves from the Soviet empire, it was essential for the new elites to enhance the victimisation narrative, emphasising the negative aspects of Stalinism, Soviet deportations, and the partisan resistance. The bloody event of Soviet aggression, which occurred on January $13^{\text {th }}, 1991$, was also very significant in terms of achieving greater legitimacy in the eyes of the international community for the new state and for mapping the visions of the country's political path. At the beginning of 1991, it became obvious that greater attention of the US and other Western countries to Lithuania could bring more security to Lithuania, and it was acknowledged that the consolidation of political forces and fewer internal conflicts could ensure further development. There was a permanent attempt coming from radical groups of Sajūidis, by using pronounced rhetoric, to launch judicial or at least actual de-Sovietization trials and actions against significant communist dignitaries, but structurally it did not remove them as a political force. There was a certain exchange: ex-communists accepted the political and economic trajectory and visions modelled by the right-wing forces. However, under the controversial modus operandi within the Lithuanian political milieu, which attempted to manoeuvre between the local, international and Soviet contexts, the ex-Communists ensured enough room to preserve their political status, while the popularity of Sajūdis declined during the years 1990-1992 ${ }^{35}$. Soon, under the conditions of rapid privatization ${ }^{36}$, many former nomenklatura members successfully participated in the prichvatization, ${ }^{37}$ becoming part of the nouveau riches group ${ }^{38}$. A certain reconciliation among the elite groups was also needed to ensure the prevention and limitation of activism of the "protest groups" (e.g., after the economic decline at the end of 1990 people were shouting slogans against the "fascist government" in some areas dominated by ethnic minorities- e.g., Šalčininkai). This discourse overlapped with the Centre's warning that Lithuania would return to the time of the bourgeoisie. In this situation, the local communists remained a significant power group and became a balancing factor against various Soviet-related "voices". However, the risk that the Polish minority would attempt to shape

${ }^{35}$ Mindaugas Tamošaitis, "Prieštaravimai Sąūjyje atkūrus Lietuvos nepriklausomybę", Istorija / History, Vol. 99, No. 3, (2015), 52-67.

${ }^{36}$ For instance, Algirdas Brazauskas supported the position of the leader of the "economist group", Kazimieras Antanavičius in March, 1991 for less quotas in the privatisation process. See Gediminas Ilgūnas, Algirdas Brazauskas (Vilnius, 1998), 52.

${ }^{37}$ Lithuania's first-wave privatization of state owned companies, which is commonly nicknamed "prichvatization" (from the Russian word "prichvatit - to grab")

${ }^{38}$ Irmina Matonyte, Posovietinio elito labirintai (Vilnius, 2001). 
their own socialist or another type of republic significantly diminished after the January events. It was noticed that in May the local congress of Lithuanian Poles supported the rather moderate autonomist ideas of Anicet Brodawski instead of the socialist-national ideas of Czeslaw Wysocki, promoting autonomy under the protection of Moscow ${ }^{39}$. The latter scenario was seen as inappropriate for local Poles and Poland. Thus, most of the local Polish community supported the idea of autonomy, but did not push the process towards separatism.

The January events provided more legitimacy for shaping and maintaining the "hawkish" position of Lithuania, rejecting any idea of negotiating the renewed status of Lithuania within the Soviet state. Lithuania had received great attention due to the bloody event, both in the USSR and in the Western countries. The Frankfurter Allgemeine Zeitung of January 14 ${ }^{\text {th }}, 1991$ commented $^{40}$ : Lithuania's freedom is broken, and the world has reason to worry about the other Baltic republics. The answer to the question, 'Is Gorbachev still master of the situation' - be the answer yes or no - is equally scary. In the first case, it is clear from the events of the military intervention on Sunday night that the will to reform has been crippled. Were perestroika and glasnost only temporary measures of a politics whose goal remained unchanged, namely the preservation of Soviet power? Czesław Miłosz, the American Nobel prize-winning poet of Polish and Lithuanian origin, wrote that: "The thrashing tail of the wounded totalitarian beast has hit Lithuania, and our concern with Middle Eastern events should not make us indifferent to the tragedy of this small nation. The military and the KGB have made a mistake by sending troops. If there was a chance the Baltic States would remain part of a federation with its center in Moscow, that chance is now lost. Without exaggeration, one can say that the blood spilled in Vilnius is the gauge of Lithuania's future as an independent country".

In response to the bloody events, a referendum for independence was held in Lithuania on February $9^{\text {th }}, 1991$, and it was approved by $93.2 \%$ of voters (76.5\% of all registered voters). Moscow declared the referendum null and void, but this confirmation consolidated the Lithuanian position at a higher level. Later Vytautas Landsbergis interpreted this referendum as the final step for legitimizing independence and remembered that he had received the idea of the referendum from the US president George H. W. Bush during their meeting on

${ }^{39}$ Atgimimas, June 20-27, 1991, 9.

${ }^{40}$ Darius Furmonavičius, “The Price of Freedom January 13, 1991 in Lithuania”, Lituanus, volume 54, no 1 (Spring 2008). See http://www.lituanus.org/2008/08_1_01-a\%20Furmanavicius. htm; also see From the editorial "The will to reform is broken" in Frankfurter Allgemeine Zeitung for January 14, 1991. In The Gift of Vilnius. A Photographic Document in Defense of Freedom. January 13, 1991. A Terrible Beauty is Born. Chicago: Public Affairs Council, Lithuanian American Community, 1991, 46; Czesław Miłosz, "Moscow's poisoned tomato." The Gift of Vilnius, 5. 
December $10^{\text {th }}, 1990^{41}$. It must be noted that the January events increasingly promoted the wider international recognition of the new Lithuanian state (e.g., Iceland recognized it in February 1991) and intensified the relationship with Western politicians and diplomats. This trend was transformed, after the breakup of the Soviet Union at the end of 1991, into the vision that "Lithuania will return to the Western world".

The Constitution of newly independent Lithuania was adopted in a referendum, which took place on October 25, 1992. The constitution ensured the establishment of a parliamentary-presidential democracy, emphasized that the historic Lithuanian nation introduced this constitution, and implemented the nation state's compatibility with democratic standards, while also ensuring the rights of national minorities by giving them the right to foster their language, culture, and customs. Despite the fact that Lithuania secured political and cultural rights for ethnic minorities, the dominant position of the politics of history became the narrative focusing on the suffering of the Lithuanian nation. For instance, the "Museum of Genocide" was founded in 1992 (with the word "genocide" referring to Soviet crimes against the Lithuanian nation). It was only in 1997 that the museum was turned into a full-scale research centre and given the more inclusive name of The Genocide and Resistance Research Centre ${ }^{42}$. The narrative foundations of post-Soviet Lithuanian identity mostly emphasized the liberation from successive occupations, Soviet deportations, Soviet-inflicted traumas, the struggle against Soviet power in the post-war period, the events of January 13, 1991, and the continuing Russian threat. Several laws, relating to the evaluation of the Soviet legacy, were adopted in Lithuania: the Law on the rehabilitation of persons repressed for resistance to the occupation regime (1990); Decree No 418 banning KGB employees and informers from government positions (1991); the Law on the Legal Status of the Citizens of the Republic of Lithuania Who Fell Victim to the Occupations of 1939-1990 (1997); the Law on State Support of the Participants of the Armed Resistance (1997); the Law on Registering, Confessions, Entry into Records and Protection of the Persons Who Have Admitted to Secret Collaboration with the Special Services of the Former USSR (1999); the Law on the Evaluation and Assessment of the USSR State Security Committee (NKVD, NKGB, MGB, KGB) and the Current Activities of the Staff Members of this Organisation (1999); the Law on Compensation of the Damage Resulting from

${ }^{41}$ Vytautas Landsbergis, Lūžis prie Baltijos. Politine autobiografija (Vilnius, 1997), 261.

${ }^{42}$ Violeta Davoliūte, "Heroes, Villains and Matters of State: The Partisan and Popular Memory in Lithuania," 17 Nov 2017. See http://www.cultures-of-history.uni-jena.de/debates/lithuania/ heroes-villains-and-matters-of-state-the-partisan-and-popular-memory-in-lithuania/ (accessed 31.05.2018). 
the Occupation by the USSR (2000), and several others. The content of this legislation provided for support for Soviet victims and former partisans, introduced certain limitations and restrictions for former KGB officers, and tackled the question of compensation of the occupation damage, which was addressed to Russia. These laws illustrated that Lithuania implemented a certain degree of de-Sovietisation (not fully, however). This strategy was based on a classification of "heroes, victims, and villains". It is important to note that this position became the modus operandi of the local politics of history ${ }^{43}$. The degree of responsibility and assessment of the Soviet past is often based on viewing totalitarianism as a practical category, by showing the constant threat of the "evil empire". This helps to legitimise the current political, cultural and economic development. At the same time, this politicization of history serves as a tool for confronting and resisting Russia's policies in the region.

The early period of Lithuania's independence (1990-2004) was mainly concerned with the consolidation of the recently regained independence and with achieving the broadly supported goal of the full membership in the European Union and NATO. When Putin came to power and Russia began to develop its authoritarian tendencies, the Lithuanians started to publicly voice their alarm concerning Russia's threat at the international level. For instance, President Valdas Adamkus's foreign policy vision, articulated during 2004-2009, searched for closer cooperation with Poland and was also influenced by the Giedroyc-Mieroszewski political doctrine ${ }^{44}$, which was developed in the Polish émigré literary-political journal Kultura. It proposed a concept of Polish Eastern policy based on the close cooperation between Poland, Lithuania, Belarus, and Ukraine. After the Georgian-Russian war of 2008, and especially following Russia's aggression in Ukraine in 2014, Lithuania became the country which loudly denounced Russia's aggression, its hybrid threats, its information wars, etc. The events in Ukraine in 2014 reshaped President Dalia Grybauskaite's policy; she moved from her previous pragmatism to a "Cold warrior" position. The major part of the elite supported and still supports Grybauskaite's new position ${ }^{45}$. In March 2014, just before the Lithuanian Presidential elections, 87 percent of Lithuanians believed that there was a "real threat" of Russia's military attack on Lithuania, while in

${ }^{43}$ Violeta Davoliūte and Tomas Balkelis point out that some cases of "legislated history", for example, the lustration of former KGB agents and court trials of perpetrators of past crimes, were only partially successful, fragmentary and, therefore, barely achieved their aims. See Tomas Balkelis and Violeta Davoliūte, "Legislated History in Post-Communist Lithuania" The Palgrave Handbook of State-Sponsored History After 1945 (Palgrave Macmillan, 2018), 121-138.

${ }^{44}$ Marcin Celinski, The Giedroyc era ended in foreign policy. March 8, 2011.

${ }^{45}$ Linas Kojala, Vilius Ivanauskas, "Lithuanian Eastern Policy in 2004-2014: Role theory approach”, Lithuanian Foreign Policy Review, no. 32 (2014): 49-72. 
2012 more than 60 percent said that Lithuania did not face "any direct threats" 46 . Now there is a smaller percentage of the population who think that Russia could directly attack. A part of the Lithuanian society wants better relations with Russia, but demands more caution about it. Lithuania is a NATO member country, which has good relations with the US and is part of the EU, but it does not have any guarantees from Russia. With Russia's growing influence on the Brexit results, on the US election and elsewhere, it became clear that Russia can affect not only the Eastern partnership countries, not only the Baltic and Central European countries, but also "old Western democracies, like Germany, France, the UK and the US" ${ }^{47}$. The legitimacy of the current regime in Russia is based on its continuous demonstration of victories, which helps to mobilize support for $\mathrm{Pu}$ tin. At the same time, Russia is using an aggressive politics of history, describing the Soviet occupation of Lithuania as liberation from fascism and also arguing that Lithuanian post-war resistance was carried out by criminal bands. It also focuses on showing Lithuanians as sympathetic to fascism ${ }^{48}$. This position affects Lithuania's perception of security and influences the uses of politics of history as well. After Russia's annexation of Crimea and its aggression against Ukraine, Lithuania has strengthened the narrative of the post-war partisan struggle as a foundational moment. It is now perceived as a tool for building the resilience of the nation. The elevation of the anti-Soviet resistance fighters to the position of the highest moral authority is widely accepted ${ }^{49}$, but, at the same time, it becomes a hindering factor for free discussions. Memory wars began mainly due to the habit of ideologizing the history of the Soviet era, which was also noticeable in the post-Soviet period. These debates also served to crystallize the doctrines of various political forces, or to strengthen populism, which presupposed a strict imposition of one dominant version of historical truth, leaving less space for free discussions. As historian Violeta Davoliūte points out, the case of the famous Lithuanian writer Rūta Vanagaite, which happened at the end of 2017, revealed these internal tensions. The Lithuanian Parliament was planning to dedicate the year 2018, the one hundredth anniversary of Lithuanian independence, to

${ }^{46}$ Visuomenès nuomonès tyrimas šalies saugumo ir gynybos klausimais (Public opinion research on the country's security and defence) see http://www.spinter.lt/site/lt/vidinis/menutop/9/ home/publish/\%20NjAyOzk7OzA $=$ (accessed 31.05.2018).

${ }^{47}$ Jonathan Masters, Russia, Trump, and the 2016 U.S. Election, February 26, 2018, see https:// www.cfr.org/backgrounder/russia-trump-and-2016-us-election (accessed 31.05.2018).

${ }^{48} \mathrm{http}: / /$ www.ntv.ru/video/1563488/ (accessed 31.05.2018).

${ }^{49}$ Violeta Davoliūte, "Heroes, Villains and Matters of State: The Partisan and Popular Memory in Lithuania", 17.11.2017. See http://www.cultures-of-history.uni-jena.de/debates/lithuania/ heroes-villains-and-matters-of-state-the-partisan-and-popular-memory-in-lithuania/ (accessed 31.05.2018). 
the memory of Adolfas Ramanauskas-Vanagas, a former partisan leader. In the midst of these deliberations, Rūta Vanagaite, during a TV interview, made the sensational declaration that Ramanauskas-Vanagas, who was brutally tortured by KGB interrogators in 1956, had not only possibly participated in the Holocaust, but had presumably collaborated with the KGB as well ${ }^{50}$. As the further debate showed, Rūta Vanagaitè made uncritical use of Soviet sources. However, the harsh criticism towards her, including her massive condemnation by dominant local politicians, intellectuals, and other opinion leaders resulted in the withdrawal of all her books from the shelves, including her book "Mūsiškiai" (an influential work about Lithuanians' participation in the Holocaust). These events illustrated the fact that the politics of history in certain situations also becomes a challenge to free speech, while "nationalising nationalism" could establish a restrictive monopoly on "good" patriotism and a simplified interpretation based on a hierarchy of internal traitors. This might represent a risky tendency to move towards the current unpleasant situation of Hungary and Poland, which display some features of illiberal democracy ${ }^{51}$ and implement a harsh politics of history, while avoiding certain 'uncomfortable' historical moments and events (e.g., the Holocaust $)^{52}$. However, currently Lithuania still follows the path of liberal democracy and meets relatively high standards of democracy development. Lithuania ranks $37^{\text {th }}$ in the world according to the democracy index, while Poland is in the $53^{\text {rd }}$ place and Hungary is the $56^{\text {th }}$ worldwide ${ }^{53}$.

\section{Rezumat}

Lituania modernă s-a dezvoltat mai ales drept răspuns la un șir de provocări externe și interne. În timpul renașterii națiunii moderne, în secolul al XIXlea, au apărut mai mulți vectori care au influențat în mod constant discursurile, politica și mișcarea de rezistență intelectuală. În primul rând, a fost

${ }^{50}$ Violeta Davoliūte, "Heroes, Villains and Matters of State: The Partisan and Popular Memory in Lithuania", 17. Nov 2017. See http://www.cultures-of-history.uni-jena.de/debates/lithuania/ heroes-villains-and-matters-of-state-th"e-partisan-and-popular-memory-in-lithuania/_ (accessed 31.05.2018).

${ }^{51}$ Aron Buzogány, "Illiberal democracy in Hungary: authoritarian diffusion or domestic causation?", Democratization, volume 24, issue 7 (2017): 1307-1325; "Illiberal democracy on the rise? The case of Hungary and Poland,", see https://www.futurelearn.com/courses/european-culture/0/steps/2354 (accessed 31.05.2018).

${ }_{52}$ Mateusz Mazzini, Poland's right-wing government is rewriting history — with itself as hero, The Washington Post, February 27, 2018, see https://www.washingtonpost.com/news/monkeycage/wp/2018/02/27/polands-right-wing-government-is-rewriting-history-with-itself-ashero/?utm term $=.37 \mathrm{c} 34 \mathrm{c} 8 \mathrm{bd} 905$ (accessed 31.05.2018).

${ }^{53}$ Democracy Index 2017 Free speech under attack, The Economist, see http://pages.eiu.com/ rs/753-RIQ-438/images/Democracy_Index_2017.pdf (accessed 31.05.2018). 
vorba despre dezvoltarea ideologiei naționale, care viza garantarea dreptului națiunii lituaniene de a înființa un stat independent. În al doilea rând, dezvoltarea democraţiei a devenit tot mai evidentă în procesul de cristalizare și dezvoltare a statului independent. Acest articol încearcă să arate dezvoltarea și suprapunerea ideologiei și democrației în vadrul statului și a mișcării naționale, subliniind principalele provocări cu care se confruntă istoria Lituaniei moderne. Articolul discută istoria Lituaniei interbelice, al doilea război mondial, ocupația sovietică, precum și Lituania contemporană. Autorul descre situația țării, urmărind principalele elemente ale traiectoriilor politice și ideologice lituaniene, inclusiv politica locală a istoriei. Prin abordarea conceptului de națiune ca o „categorie practică”, autorul observă că naționalismul a devenit un factor important nu numai pentru eliberarea de sub dominația și ocupațiile imperiale (Rusia și URSS), dar și pentru justificarea noii ordini în noul stat independent sau chiar și atunci când democrația era contestată. Cu toate acestea, dezvoltarea democrației coexista în multe situații cu manifestările caracteristice ale naționalismului. Totuși, în anumite perioade ale istoriei moderne lituaniene, această coabitare a devenit problematică și a fost definită de experiențe asemănătoare celor din alte țări din Europa Centrală și de Est. Aceste experiențe însemnau fie confruntarea cu tendințele autocrate din perioada interbelică, fie trebuiau să răspundă cumva populismului în creștere legat de evoluțiile politice recente. Prezența dominantă a Rusiei Țariste, a Uniunii Sovietice și a Rusiei lui Putin a jucat întotdeauna un rol semnificativ în tendința fermă a Lituaniei de a se consolida ca un stat-națiune. Această experiență afectează puternic nu numai actuala orientare geopolitică a țării, ci și mobilizarea patriotismului (naționalismului), dar mai ales politica istoriei din Lituania. Argumentul privind responsabilitatea trecutului sovietic pentru traumele colective se bazează adesea pe interpretarea totalitarismului ca o categorie practică, accentuând și demascând amenințarea constantă a „imperiului răului”, care contribuie la legitimizarea dezvoltării politice, culturale și economice actuale a statului. În același timp, această politizare a istoriei servește ca un instrument eficient în combaterea și rezistența față de politicile Rusiei din regiune.

Cuvinte cheie: naționalism, ideologie națională, democrație, Lituania, independenţă, centenar, politica istoriei, Uniunea Sovietică, Rusia. 